\title{
NEONATUS DENGAN IKTERIK
}

\section{NEONATAL CARE WITH JAUNDICE}

\author{
Rosy Febriasari ${ }^{1}$, Nurwinda Saputri ${ }^{2}$, Wahyu Widayati ${ }^{3}$, Dzul Istiqomah Hasyim ${ }^{4}$ \\ ${ }^{123}$ Fakultas Kesehatan Universitas Muhammdiyah Pringsewu \\ Email Correspondence: nurwindasaputri17@gmail.com
}

\begin{abstract}
Neonatal Care with Jaundice. Until now, jaundice is still a problem in neonates that is often faced by health workers, occurring in about $25-50 \%$ of term neonates and higher in preterm neonates. clinic baby. Design This study uses a case study, conducted to identify comprehensive neonatal midwifery care in Neonatal Care. The samples taken were neonates in care at PMB Sulastri, S.ST. This research method uses observation and descriptive method. Observations were made using Varney's mindset and documentation in the form of SOAP. The results of the case study show that the implementation of Neonatal Midwifery Care with Jaundice is carried out by providing care according to standard operating procedures and preventing other complications during the neonatal visit process.
\end{abstract}

Keywords: Neonate, Jaundice, Yellow

\begin{abstract}
Abstrak: Neonatus dengan Ikterik. Sampai saat ini ikterus masih merupakan masalah pada neonatus yang sering dihadapi tenaga kesehatan terjadi pada sekitar 25-50\% neonatus cukup bulan dan lebih tinggi pada neonatus kurang bulan.Oleh sebab itu memeriksa ikterus pada neonatus harus dilakukan pada waktu melakukan kunjungan neonatal/pada saat memeriksa bayi diklinik. Desaign Penelitian ini menggunakan Studi kasus, dilakukan untuk melakukan identifikasi asuhan kebidanan neonatus secara komprehensif dalam Neonatal Care. Sampel yang di ambil adalah neonatus dalam asuhan di PMB Sulastri, S.ST. Metode penelitian ini menggunakan metode observasi dan dengan cara deskriptif. Observasi yang dilakukan menggunakan pola pikir Varney dan pendokumentasian dalam bentuk SOAP. Hasil studi kasus menunjukan pelaksanaan Asuhan Kebidanan Neonatus dengan Ikterus yang dilakukan dengan pemberian asuhan sesuai standart operasional prosedur serta melakukan pencegahan komplikasi yang lain pada saat proses kunjungan neonatus.
\end{abstract}

Kata Kunci : Neonatus, Ikterik, Kuning

\section{PENDAHULUAN}

Penanganan bayi baru lahir memerlukan upaya bersama tenaga kesehatan khususnya bidan dengan memberikan asuhan komprehensif sesuai dengan PerMenKes RI No.1464/MenKes/2010 sejak bayi dalam kandungan, selama persalinan segera sesudah melahirkan serta melibatkan keluarga dan masyarakat dalam memberikan pelayanan kesehatan yang berkualitas seperti mengajar cara merawat tali pusat, cara memandikan bayi serta memberi ASI Esklusif dan pemantauan pertumbuhan dan perkembangan selanjutnya akan menghasilkan bayi sehat. Empat negara termasuk Indonesia diantara Filipina, Laos dan Kamboja termasuk kelompok sedang. Sedangkan ke lima negara lainnya yaitu Singapura, Malaysia, Brunei Darussalam, Thailand dan Vietnam termasuk negara dengan Angka Kematian Bayi rendah. Dari 10 negara anggota ASEAN, tidak ada yang masuk dalam kelompok angka kematian bayi sangat tinggi (>100 per 1.000 kelahiran hidup).

Sampai saat ini ikterus masih merupakan masalah pada neonatus yang sering dihadapi tenaga kesehatan terjadi pada sekitar 25-50\% neonatus cukup bulan dan lebih tinggi pada neonatus kurang 
bulan.Oleh sebab itu memeriksa ikterus pada neonatus harus dilakukan pada waktu melakukan kunjungan neonatal/pada saat memeriksa bayi diklinik.

Kadar bilirubin yang cukup berlebihan ini dapat menyebab kan kerusakan pada otak yang permanen atau disebut juga dengan kernicterus, dalam hal ini sebanyak $60 \%$ dari beberapa bayi yang sehat dapat mengalami penyakit icterus atau kuning dan sekitar $75 \%$ bayi dilakukan perawatan di Rumah Sakit dan beberapa kasus banyak yang terjadi di usia pertama kelahiran bayi. Adapun peningkatan kadar bilirubin ini diatas normal yang sering terjadi pada bayi Premature sebanyak $80 \%$ dan pada bayi yang cukup bulan sebanyak 60\% di minggu pertama setelah lahir. (Anggraini, 2016)

Peningkatan pada kadar bilirubin dalam darah ini disebabkan oleh bilirubin yang tidak terkonjugasi dengan baik disebabkan oleh organ hati pada neonates ini tidak mampu membersihkan bilirubin dalam darah dengan cepat, sehingga kalori dan cairan terrundanya buang air besar yang membuat bayi menjadi kuning. Adapun jenis penyakit icterus ini adalah fisologis dan patologis. Untuk icterus fisiologis ini tidak berbahaya bila penanganan cepat dan tepat. Bila mengarah ke patologis maka harus segera ditangani medis. (Hanisamurti, 2018) (Hasyim and Saputri, 2019)

\section{METODE}

Jenis penelitian ini adalah deskriptif dengan pendekatan studi kasus Asuhan Kebidanan Neonatus Pada BY.L dengan Ikterus. Penelitian dilakukan di PMB Sulasti, S.ST Pringsewu Lampung. Sasaran pada penelitian yaitu neonates. Jalannya penelitian dimulai dari persiapan penelitian, Menentukan pasien setelah disetujui kemudian tahap pelaksanaan meliputi meminta persetujuan pasien atau informend consent, melakukan penelitian pada pasien dengan ikterus, lalu pengumpulan data, editing, kemudian menyimpulkan hasil penelitian, presentasi hasil penelitian, kemudian perbaikan laporan penelitian dan publikasi. Insturmen yang digunakan adalah lembar observasi melihat langsung tanda dan gejala ikterik, dan kejadian ikterik ini dilihat dari warna kulit bayi. Penelitian sesuai dengan 7 langkah Varney dan Pendokumentasian dalam bentuk SOAP.

\section{HASIL}

Pada Kasus Asuhan Kebidanan pada Neonatus By. L dengan Ikterik ini dimulai dengan anamamnesa pada ibu dengan memeriksa keadaaan umum bayi terlihat sedang tidur. Kemudian dilakukan pemeriksaan fisik dengan memperhatikan derajat Kramer pada bayi, hasil pemeriksaan kulit bayi berwarna sedikit kuning di are kepala saja. Untuk mengatasi masalah ini maka penulis memberikan konsling tentang pentingnya memberikan ASI kepada bayi secara ondemand atau bila bayi tidur lebih dari dua jam, maka ibu harus tetap memberikan kepada bayi dengan bayi di bangunkan dari tidur.

\section{PEMBAHASAN}

1. Subjektif

Berdasarkan data subjektif pada kasus By. L, ibu mengatakan anak tidak mau minum karna tidur terus, dan saat tidur ibu tidak membangunkan anaknya. Dalam teori Rohani dkk tahun 2012

$$
\text { https://ejournal.umpri.ac.id/index.php/JIK } 150
$$


mengatakan bahwa data subjektif adalah informasi yang di peroleh dari apa yang di katakan pasien tersebut. Perubahan warna kekuningan pada area tubuh terutama kulit ini menandakan tingginya kadar bilirubin, gejala yang mungkin saja ada termasuk kantuk yang berlebihan dan makan yang menurun dalam hal ini menyusui. (Colletti, JE; Kothari, S; Kothori, S; Jackson, DM; Kilgore, KP; Barringer, 2017)

2. Objektif

Dalam teori data objektif yaitu data yang di peroleh dari apa yang dilihat dan di rasakan oleh bidan sewaktu melakukan pemeriksaan dan hasil laboraturium. (Rohani dkk, 2011). Dalam melakukan identifikasi data objektif untuk menegakkan diagnosa pada kasus By. L di dapatkan hasil pemeriksaan fisik pada bagian kepala bayi dilakukan inpskesi dengan hasil kulit bagian kepala berwarna kuning (pucat).

3. Assesment

Pada kasus By. L berdasarkan data subjektif dan objektif yang diperoleh penulis mengidentifikasi diagnosa masalah yaitu: By. L dalam masa neonatus dengan ikterik. Dalam teori olusannya Mengatakan bahawa pengakan diagnosis icterus ini harus menggunakan serum bilirubin dalam darah untuk tindakan selanjutnya yang dilakuan di laboratorium. Bayi yang lahir setelah 35 minggu yang terdeteksi icterus juga dapat dilakukan hal yang sama. (Olusanya, BO; Teeple, S; Kassebaum, 2018)

4. Planning

Penganan icterus ini dilakukakn oelh tenaga kesehatan dengan beberapa cara, bila bayi kuning fisiologis maka tahap pertama yang harus dilakukan yaitu bila bayi cukup bulan maka icterus akan berlangsung sekitar 10 hari dengan peningkatan pesar bilirubin serum sampai 12 $\mathrm{mg} / \mathrm{dL}$ ). Bila bayi premature biasanya icterus akan berlasung selama 2 minggu dengan peningkatan kadar bilirubin serum 15,r/dl. Fase kedua biasanya bilirubin akan menurun sekitar $2 \mathrm{mg} / \mathrm{dl}$ selama dua minggu. Untuk bayi yang premature fase dua nya dapat bertahan lebih sekitar satu bulan dan bayi yang disusui secara ekslusid fase kedua nya akan bertahan lebih dari saru bulan. Mekanisme kerja icterus fisioligis ini adalah adanya enzim glucoronosyltranferase yang rendahsehingga dapat merubah bilirubin tak terkonjugasi menjadi bilirubin yang terkonjugasi melalui saluran pencernaan. (Rashmi A. Joshi, 2012)

Penyebab non organic ini karna menyusui yang kurang, sehingga ASI yang tidak mencukupi membuat jumlah buang air besar bayi yang tidak memadai sehingga bilirubin menurun, hal ini membuat peningkatan pada sirkulasi enterohepatik yang menhasilkan reabsorpsi bilirubin pada usus. Hal ini biasanya terjadi di minggu pertama kehidupan, dan sebagian besar kassus dapat di obati dengan baik bila di berikan Air Susu Ibu dengan ondemand.(Mancuso, 2017)

Hal ini sesuai dengan penelitian rahmadeli yang mengatakan bahwa bayi yang diberikan ASI lebih awal di pertama kelahirannya maka sangat efektif dalam mengurangi kejadian hiperbiirubin fisiologis terutama pemberian colostrum, Keefektifan ini meliputi frekuensi, durasi, serta tata cara pemberian ASI yang benar. (Rahmadeli, 2016). Penelitian polham 2015 yang bertujuan mengidentifikasi hubungan antara IMD dengan icterus menunjukkan hasil bahwaa adanya hubungan antara IMD dengan icterus ditunjukkan dengan responden yang telah diberikan ASI pertama kali $<1$ jam setelah kelahirannya ternyata tetap terjadi icterus pada sebagian kecil yaitu 2,5\% dan didapatkan derajat Kramer 1 pada bayi yang disusui <8 kali perhari.

Penanganan pada By.L dengan ikterus ini selanjutnya memberikan asuhan dengan menganjurkan ibu untuk melakukan menjemur bayinya dibawah sinar matahari pagi pukul 
07.00-08.00 WIB. Hal ini sesuai dengan teori Rukiyah (2012), penanganan bayi dengan ikterus fisiologis bisa dengan menjemur bayi di bawah sinar matahari pagi pukul 07.00-08.00 wib selama 15-30 menit dengan cara membuka seluruh pakaian bayi kecuali alat vital, dan menutup bagian mata. Selanjunya merubah posisi bagi agar sinar matahari dapat merata keseluruh tubuh.

\section{SIMPULAN}

Hasil asuhan kebidanan neonates, bayi dan balita ini disimpulkan bahwa penyebab bayi icterus adalah karna kurangnya pemberian ASI yang ekslusif oleh ibu dikarenakan bayi tidur dan tidak dibangunkan dengan alasan kasihan, sehingga asuhan nutrisi ASI tidak mencukupi bayi. Setelah dilakukan beberapa tindakan dan konseling sesuai SOP maka ibu memahami pentingnya ASI yang diberikan secara On demand

\section{SARAN}

Lahan Praktik : Sebagai bahan masukan dalam melaksanakan tindakan dan meningkatkan asuhan kebidanan pada bayi baru lahir harus konsisten untuk tetap selalu memperhatikan standar operasional prosedur.

\section{DAFTAR PUSTAKA}

Anggraini, H. (2016) 'Faktor-faktor yang Berhubungan dengan Kejadian Ikterus pada Neonatal', Jurnal Aisyah: Jurnal Ilmu Kesehatan, 2(1).

Colletti, JE; Kothari, S; Kothori, S; Jackson, DM; Kilgore, KP; Barringer, K. (2017) “Pendekatan pengobatan darurat untuk hiperbilirubinemia neonatal". muncul.', Med. klinik Am Utara ., 25(4), pp. 1117-35, vii. doi: 10.1016/j.emc.2007.07.007.

Hanisamurti, L. (2018) Pengaruh Fototerapi Terhadap Derajat Ikterik pada Neonatus di Rumah Sakit Muhammadiyah Palembang. Palembang (ID): Universitas Muhammadiyah Palembang.

Hasyim, D. I. and Saputri, N. (2019) 'PENDIDIKAN KESEHATAN TANDA BAHAYA BAYI BARU LAHIR SEBAGAI UPAYA PENCEGAHAN MORBIDITAS DAN MORTALITAS PADA BAYI BARU LAHIR', Jurnal Pengabdian Masyarakat Teknik, 2(1).

Mancuso, C. (2017) '“Bilirubin dan otak: Pendekatan farmakologis"., Neurofarmakologi, 118, pp. 113-123. doi: 10.1016/j.neuropharm.

Olusanya, BO; Teeple, S; Kassebaum, N. (2018) “"Kontribusi Penyakit Kuning Neonatal Terhadap Kematian Anak Global: Temuan Dari Studi GBD 2016" .', Pediatri ., 141((2)). doi: 10.1542/peds.2017-1471.

Rahmadeli, R. (2016) HUBUNGAN KEEFEKTIFAN PEMBERIAN ASI DENGAN DERAJAT IKTERIK BAYI HIPERBILIRUBINEMIA FISIOLOGIS DI RUANGAN PERINATOLOGI RSUP. DR. M. DJAMIL PADANG.

Rashmi A. Joshi, B. J. (2012) Soal Pilihan Ganda dalam Fisiologi B. Jain Bhms Soal Makalah. B. Jain Publishers. 